\title{
A LUTA PELA ÉTICA \\ NO ENSINO FUNDAMENTAL: \\ RELIGIOSA OU LAICA?
}

\author{
LUIZ ANTÔNIO CUNHA \\ Professor Titular do Núcleo de Estudos em Políticas Públicas \\ de Direitos Humanos, Universidade Federal do Rio de Janeiro \\ www.luizantonio.cunha.nom.br
}

\section{RESUMO}

Este artigo identifica um conflito entre dois conceitos de Ética no currículo das escolas públicas de ensino fundamental no Brasil contemporâneo. De um lado, a Ética laica, fundamentada nos provisórios consensos político-ideológicos; de outro, a Ética religiosa, convergente com uma Educação Moral e Cívica de conteúdo religioso. Esse conflito conceitual é explicado pelo autor como produto de um conflito político em torno da autonomia do campo educacional. EDUCAÇÃO PÚBLICA - ÉTICA - CURRÍCULOS - EDUCAÇÃO MORAL E CÍVICA

\section{ABSTRACT}

THE STRUGGLE FOR ETHICS IN PRIMARY SCHOOL: RELIGIOUS OR SECULAR? This article identifies a conflict between two concepts of ethics in the primary public school curriculum in contemporary Brazil. On one hand, secular ethics, grounded in a transitory political-ideological consensus; on the other hand, religious ethics converging with civic and moral education of a religious nature. This conceptual conflict is explained by the author as the result of a political conflict over autonomy in the educational realm.

PUBLIC EDUCATION - ETHICS - CURRICULUM - MORAL EDUCATION

O autor agradece os comentários de Ana Maria Cavaliere, Antonio Flavio Barbosa Moreira, Carlos Roberto Jamil Cury e Renato José de Oliveira, que contribuíram para o aperfeiçoamento do texto, mas assume toda a responsabilidade pelas incorreções e insuficiências remanescentes. 
Ética se aprende na escola? Se sim, como se dá esse aprendizado e como ele deve ser desenvolvido? Esta é uma importante questão de Filosofia da Educação, com indescartáveis dimensões históricas, sociológicas e pedagógicas. Mas, no Brasil, nessa, como em tantas outras, a ação precedeu e se impôs à reflexão. Antes que a questão tivesse sido posta e discutida, trava-se uma luta no campo educacional, em especial no ensino fundamental, sobre a natureza da Ética que, por suposto, deve fazer parte do currículo escolar.

A pergunta sobre sua presença no currículo tem sido respondida afirmativamente, de modo implícito, tanto em textos de circulação acadêmica quanto na imprensa diária. $\bigcirc$ debate é sobre o conteúdo desse ensino. De um lado estão os que defendem a Ética laica, em se tratando da escola pública; de outro, os defensores de seu conteúdo essencialmente religioso'. Esse conflito conceitual é efeito de uma luta latente mas decisiva para o processo de autonomização do campo educacional, razão pela qual se impõe a transformação do que é hoje uma luta implícita num debate aberto e racional.

Este artigo propõe-se a contribuir para tal explicitação. Para isso, lança mão de elementos históricos e sociológicos para a construção de um quadro de referência que possa ser útil para o conhecimento objetivo da questão (protagonistas, procedimentos e projetos), assim como seu correto encaminhamento.

Para o início do raciocínio aqui desenvolvido, cabe sublinhar, antes de tudo, a dimensão política dos currículos escolares. O rastreamento da legislação educacional brasileira aponta, inequivocamente, na direção da flexibilização curricular. No tempo do Império e até mesmo na República, pelo menos até a primeira Lei de Diretrizes e Bases da Educação Nacional - LDB -, de 1961, a legislação determinava as disciplinas a serem ensinadas, em cada série, do ensino primário ao superior. Neste grau prevaleciam os currículos mínimos para cada curso que visasse diploma de profissão regulamentada. A segunda Lei de Diretrizes e Bases, de 1996, deu mais um passo na direção da flexibilidade curricular, ao suprimir os currículos mínimos do ensino superior, sujeito, então, apenas a diretrizes curriculares, como o ensino fundamental e médio.

I. Além da Ética laica, publicamente sancionada, há uma Ética secular, em constante mudança, no âmbito dos grupos sociais, que se contrapõe, também, à Ética religiosa, em questões como os direitos sexuais e reprodutivos, por exemplo. Em consequência da ação política, elementos da Ética secular são assumidos pela Ética laica. O divórcio, só legalizado no Brasil em 1977, é um exemplo relevante desse movimento. 
Mas, à medida que avança essa flexibilidade, surge um movimento contrário, que procura restringi-la. Tudo começa com um grupo de interesse que mobiliza apoio político - no Executivo ou no Legislativo (municipal, estadual, mas de preferência federal) - para conseguir a edição de uma norma que determine a obrigatoriedade da inserção do elemento de seu interesse nos currículos de todas as escolas; se não de todas, pelo menos nas redes públicas de ensino. $\bigcirc$ interesse real defendido pode ser de ordem econômica ${ }^{2}$, de ordem político-ideológica ou de ambas, o caso mais frequente. Uma disciplina obrigatória é a preferência geral. Justificativas diversas procuram fazer crer que esse interesse particular é bom para todos.

Quanto mais elevada a instância política de normatização, maior o efeito obtido. A Constituição é, sem dúvida, a meta preferida. Por ser mais difícil de ser revertida a norma incluída e por ter maior abrangência, ela constitui o desaguadouro de todos os grupos de interesse ${ }^{3}$.

Em termos cronológicos, a Ética entrou no currículo escolar brasileiro com o nome de Moral, como substituta da religião ${ }^{4}$. Nas quatro primeiras décadas da República, o Ensino Religioso foi suprimido das escolas públicas, por efeito do dispositivo constitucional que determinou a independência do Estado em relação às instituições religiosas. No lugar da religião foi introduzida no ginásio, em alguns momentos, a disciplina Moral (com e sem o complemento "e Cívica"), de feição positivista. Nos anos 1920, a militância católica, organizada sob a liderança do cardeal Sebastião Leme e de um verdadeiro aparato de produção e difusão ideológica, logrou situar-se no campo político como solução eficaz para a produção da ordem, ameaçada, primeiro, pelos movimentos dos trabalhadores, depois, pelas insurreições militares. Desde sua vitória, em 1931, verifica-se a presença continuada do Ensino Religioso nas escolas públicas, ao passo que a Educação Moral e Cívica tem ocorrência inter-

2. Reserva de mercado de trabalho ou aquisição compulsória de mercadorias, como livros e equipamentos.

3. Eis aí uma explicação para a extensão e o detalhamento das constituições brasileiras. $\bigcirc$ que tem sido atribuído a um traço cultural atávico, deve ser explicado pelos conflitos de interesse e a defesa das conquistas conjunturais de grupos sociais concretos.

4. Na argumentação aqui desenvolvida, os termos Moral e Ética são empregados como sinônimos. Para o leitor interessado em sua distinção, sugiro a leitura de Taille et al. (2004) e Oliveira (2008). 
mitente, mas convergente no conteúdo. Só mais recentemente, já na década de 1990, foi que a Ética, entendida numa perspectiva laica não positivista, foi explicitada e normatizada no currículo do ensino fundamental.

A análise do processo aqui anunciado será feita segundo três movimentos, definidos de modo não cronológico, mas sistemático. Será apresentado, antes de tudo, o movimento mais recente, ou seja, o da Ética laica inscrita nos Parâmetros Curriculares Nacionais para o Ensino Fundamental - PCN; em seguida, será apresentada a reinserção do Ensino Religioso nas escolas públicas; finalmente, a Educação Moral e Cívica, assim como os projetos similares posteriores à LDB-96.

Se esses três movimentos têm na sua gênese distintas cronologias, eles estão hoje presentes no campo educacional, correspondendo a diferentes projetos para a Ética no ensino fundamental.

\section{I․ MOVIMENTO: A ÉTICA LAICA NOS PCN}

Dois pontos merecem ser destacados, preliminarmente, nesse movimento: os Parâmetros Curriculares Nacionais - PCN - para o Ensino Fundamental foram elaborados no interior do campo educacional e contêm uma Ética laica.

Os PCN foram elaborados logo ao início da gestão de Paulo Renato Sousa no Ministério da Educação ( $1995 / 2002)$. O projeto contou com a participação de professores de uma escola privada de São Paulo, reuniu numerosos assessores e recorreu à consultoria de César Coll, especialista espanhol em questões curriculares, inspirador da reforma educacional de seu país natal ${ }^{5}$. Em dezembro de 1995, uma versão preliminar dos PCN foi enviada às várias instâncias dos sistemas educacionais, assim como a numerosos docentes-pesquisadores universitários, a quem o MEC solicitou parecer. A versão reelaborada foi enviada ao Conselho Nacional de Educação, cuja Câmara de Educação Básica aprovou os PCN, pelo Parecer n. 4/98, mas não os tornou obrigatórios. Com base nos parâmetros, as Diretrizes Curriculares Nacionais foram aprovadas pela Resolução n. 2/98.

Não é este o lugar para se fazer o exame do processo de elaboração dos PCN, sobre o que existe, aliás, ampla bibliografia, inclusive teses e dissertações

5. Para uma crítica da obra de Coll, remeto o leitor a Moreira ( 1997$)$. 
acadêmicas. Limito-me a mencionar o que disse em artigo publicado no calor da hora, no qual reclamei da pressa no processo de elaboração, do descarte da colaboração institucional das universidades e institutos de pesquisa, assim como da desconsideração para com o grande esforço de construção curricular que vinha sendo desenvolvido, havia anos, em vários estados e municípios, esforço esse que foi atropelado pelo MEC. A propósito, esse artigo resultou de parecer elaborado a pedido da Secretaria do Ensino Fundamental, em julho de 1996, sobre o tema transversal Convívio Social e Ética. (Cunha, 1996)

Nesse parecer/artigo critiquei vários elementos da versão preliminar desse tema transversal, que não vou retomar aqui nem cotejar com a versão finalmente aprovada pelo CNE. Para os fins deste texto, basta registrar que a escola foi erigida, pelos PCN, em "agência privilegiada de formação para a cidadania”. A escola seria uma espécie de antecipação das relações sociais que se pretendia generalizar na sociedade. Cada aluno aprenderia nela a respeitar e ser respeitado, a ouvir e a ser ouvido, a reivindicar direitos e cumprir com suas obrigações.

Apontei a existência, na versão preliminar dos PCN, de total silêncio sobre o Ensino Religioso, apenas mencionado como sendo disciplina de matrícula opcional. Sobre a Educação Moral e Cívica, nenhuma palavra. Ora, estava claro, para mim, que o tema transversal Convívio Social e Ética pretendia disputar o espaço ocupado por aquelas disciplinas no ensino fundamental. Como a concepção daquele tema transversal continha uma Ética laica, abria-se uma disputa, no currículo da escola pública, por um espaço que tem sido tradicionalmente ocupado pelo Ensino Religioso e pela Educação Moral e Cívica. Mas, ao invés de definir claramente o adversário e partir para o confronto, os PCN apresentavam apenas o que se pretendia fazer, como se aquelas disciplinas não existissem. Levantei a hipótese de existência do artifício político-prático de apagamento do oponente, talvez com o objetivo de não suscitar oposição, especialmente das organizações religiosas. A versão final dos PCN manteve essas características.

No artigo de 1996, sugeri que Convívio Social e Ética fosse retirado dos parâmetros, pelo menos no que dizia respeito ao ensino voltado para o aluno. Por outro lado, reconhecia que eles continham ensinamentos preciosos, apontando uma direção importante para a formação de professores e demais profissionais da educação, vale dizer, para sua formação numa Ética laica. 
Passemos, então, ao tema Ética, tal como aparece formulado nos PCN, tratado como um dos Temas Transversais do currículo do ensino fundamental. (Brasil, 2000)

O desenvolvimento desse tema deveria se pautar pela autonomia moral, condição para a reflexão ética. Para isso, foram eleitos como eixos do trabalho quatro blocos de conteúdo: respeito mútuo, justiça, diálogo e solidariedade (Brasil, 2000, p.32). Os valores escolhidos e a intenção de ensiná-los deveriam ser explicitados para todos, principalmente para os alunos. $\bigcirc$ trabalho pedagógico deveria incluir a possibilidade de discussão e questionamento, assim como a não-ocultação de contradições, conflitos e confrontos. Dito de outro modo, os conflitos deveriam ser apresentados como inerentes aos processos democráticos, pois são eles que fazem avançar, não sendo algo negativo que devesse ser evitado. (Brasil, 2000, p.46-47).

Em lugar algum dos PCN os valores éticos estão baseados em textos sagrados ou em obras abstratas, mas encontram sua base num texto político concreto, resultado da negociação de diversas forças políticas: a Constituição Federal. Do art. $1^{\circ}$., os parâmetros destacam, como fundamentos da República, a dignidade da pessoa humana e o pluralismo político. Do art. $3^{\circ}$., apontam os objetivos da República: construir uma sociedade livre, justa e solidária; erradicar a pobreza e a marginalização, e reduzir as desigualdades sociais e regionais; promover o bem de todos, sem preconceitos de origem, raça, sexo, cor, idade e quaisquer outras formas de discriminação. Do art. $5^{\circ}$, extraem diversas consignas: homens e mulheres são iguais em direitos e obrigações; ninguém será submetido a tortura nem a tratamento desumano ou degradante; é inviolável o direito de consciência e de crença; e outras. (Brasil, 2000, p.70-7I).

Em suma, a Ética é concebida como imanente à vida social, sendo a Constituição a expressão dos valores acordados pelas diversas forças políticas em confronto.

Não tenho dúvida de que os PCN apontam uma direção importante para a formação inicial e continuada dos professores e dos demais profissionais da educação. A reflexão, por parte destes, sobre o modo como os alunos devem ser tratados pode ajudar a evitar que as atitudes e os valores negativos, vigentes na sociedade brasileira (e, em consequência, na escola brasileira) sejam reproduzidos pela atividade educativa. Esses elementos de ensinamento psicológico poderiam ser empregados na educação dos educadores, para 
que eles possam constituir um modelo socialmente válido para os alunos e, quando for o momento de intervirem mais diretamente em alguma questão, como, por exemplo, na discriminação racial e religiosa, possam fazê-lo com responsabilidade e efetividade.

No entanto, a dimensão psicológica da Ética não deve, em caso algum, substituir sua dimensão sociopolítica. $\bigcirc$ diálogo, por exemplo, não se reduz ao plano individual. Ele é um imperativo da democracia, pois concerne à manifestação das diferentes correntes de opinião e de interesse, que ultrapassam o conjunto dos indivíduos.

Passemos, agora, aos dois movimentos externos ao campo educacional, que visam a produzir efeitos internos no currículo do ensino fundamental.

\section{$2^{\circ}$. MOVIMENTO: O ENSINO RELIGIOSO NAS ESCOLAS PÚBLICAS}

Seis meses após a instalação do governo provisório que decorreu da revolução de 1930, o Ensino Religioso foi enxertado no currículo das escolas públicas primárias, secundárias e normais. Não foi um ato isolado, mas parte de um pacote de um ordenamento imposto à educação nacional ${ }^{6}$. Pelo Decreto n. 19.941, de 30 de abril de 1931, as escolas públicas poderiam oferecer essa disciplina, mas os alunos ficavam dispensados de frequentar as aulas de religião se os pais ou responsáveis o requeressem, caso contrário, eles deveriam frequentar essas aulas conforme o credo declarado ${ }^{7}$.

A exposição de motivos do Ministro da Educação, Francisco Campos, justificando o decreto, partiu do princípio de que o fim da escola implica a adoção de proposições sobre a natureza e os destinos do homem, ou seja, de uma concepção ético-religiosa da vida, a qual não pode ser ditada pelo

6. O Governo provisório, chefiado por Getúlio Vargas com base nas forças armadas e nas oligarquias dissidentes era uma ditadura, no sentido estrito. $O$ Congresso Nacional foi dissolvido e a Constituição, suspensa. Foi só depois da Revolução Constitucionalista de 1932 que foram convocadas eleições para recomposição da Câmara dos Deputados e do Senado, os quais elaboraram nova Constituição e elegeram, indiretamente, o próprio Getúlio Vargas, presidente da República.

7. Nas escolas oficiais só haveria aulas de religião, para um credo específico, se o número de interessados fosse igual ou superior a 20. Esse critério determinava a identificação de religião a catolicismo, dada a predominância de seus adeptos na população do país, principalmente na população escolarizada. 
Estado, sem violar o direito natural dos pais à educação dos filhos. Assim, o Estado deveria garantir às famílias que seus filhos tivessem o ensino da religião nas escolas oficiais, mas deixar a elas a escolha da religião a ser ensinada, assim como a opção da dispensa desse ensino.

Para o ministro, essa era uma conquista do catolicismo contra o "dogma da liberdade de pensamento" defendido por liberais, e, provisoriamente, pelos comunistas, interessados em "destruir as instituições nacionais". Numa defesa posterior daquele decreto, Campos dizia que era preciso opor a "liberdade do ensino religioso" à "liberdade de ensino" dos liberais. Portanto, esse ensino só poderia ser imposto por uma ditadura. Como na passagem extraída de um discurso proferido em 1936:

.... Ensino Religioso, para conquistar a liberdade, teria que violar um sistema político, que, na conformidade das práticas agnósticas, os liberais consideravam como uma das categorias eternas do espírito humano. A liberdade do Ensino Religioso só poderia ser, portanto, um ato revolucionário. Não poderia ser o ato de um ministro. Só o ditador, guia e intérprete da revolução, poderia quebrar grilhões, estendendo a ruptura do sistema político vigente até o dogma fundamental da liberdade de pensamento que as inspirações maçônicas e livrespensadoras do liberalismo do século XIX haviam postulado para as suas próprias crenças e os seus próprios fanatismos, excluindo do privilégio as grandes formas do pensamento e do sentimento religioso. (Campos, 1940, p. I 5 I)

A educação era considerada por Francisco Campos como um processo destinado a criar, conservar ou recuperar os valores que teriam sido perdidos - a religião, a família e a pátria -, uma tríade semelhante à do integralismo, forjada nos quadros de referência do fascismo, ideologia à qual Francisco Campos não era avesso.

A mobilização política da Igreja Católica, por ocasião da Assembleia Constituinte de 1933/34, foi vitoriosa, de modo que todos os pontos de sua plataforma foram inseridos na nova Carta, inclusive a obrigatoriedade do Ensino Religioso nas escolas públicas, em termos ainda mais favoráveis do que os do Decreto n. 19.941/31. Ao invés das escolas públicas poderem oferecer o Ensino Religioso, elas deveriam fazê-lo, e dentro do horário de aulas. A exigência de número mínimo de alunos por classe foi suprimida. Desde então, 
todas as Constituições brasileiras determinam a oferta do Ensino Religioso nas escolas públicas, aliás a única determinação curricular nesse nível da legislação. Abrangente e duradouro enxerto!

A ação religiosa sobre os sistemas de ensino, especificamente de parte da Igreja Católica, tem logrado conquistas adicionais. Como se já não bastasse a oferta obrigatória da disciplina Ensino Religioso nas escolas públicas de ensino fundamental, frequentemente obrigatório para os alunos, na prática, a despeito da cláusula facultativa, enxertos adicionais têm sido introduzidos na legislação de estados e municípios, inclusive ao arrepio da Constituição Federal. Para exemplificar, a normatização paulista será comentada a seguir ${ }^{8}$.

Em 200 I, o Conselho de Educação do Estado de São Paulo estabeleceu as normas para o Ensino Religioso nas escolas da rede estadual (Deliberação n. I6/0 I); elas determinavam o oferecimento dessa disciplina no ensino fundamental, como prescreve a Constituição Federal. Nas quatro primeiras séries (7 a 10 anos), o Ensino Religioso deveria ser ministrado como um "tema transversal”, pelo próprio docente da classe. Para os alunos da $7^{a}$ ou da $8^{a}$ séries ( 13 e 14 anos), em uma e somente uma delas, seria oferecida uma aula semanal, a ser acrescida à carga horária existente. Os docentes arregimentados para este fim deveriam pertencer à rede estadual, habilitados para o magistério das disciplinas História, Ciências Sociais ou Filosofia.

Em consequência, o Ensino Religioso tornou-se obrigatório para os alunos de 7 a 10 anos, pois, desenvolvido como "tema transversal", não lhes caberia opção. Igualmente, o Ensino Religioso tornou-se obrigatório para os docentes, ao menos em tese, pois todos eles deveriam desenvolvê-lo com os alunos, ainda que sem um horário próprio para isso. Na $7^{\mathrm{a}}$ ou na $8^{\mathrm{a}}$ séries, o caráter facultativo ficou assegurado para os alunos, pois sua matrícula dependeria do conhecimento dos pais sobre o conteúdo a ser desenvolvido, assim como de sua autorização expressa. Também os professores fariam, voluntariamente, a opção de lecionar tal disciplina.

Em 2002, a Coordenadoria de Estudos e Normas Pedagógicas estabeleceu o conteúdo do Ensino Religioso nas escolas estaduais paulistas, com base na Deliberação do Conselho Estadual de Educação. Nas séries iniciais, o sentido ético da vida em grupo seria o principal elemento do conteúdo, no qual o do-

8. Para uma análise detalhada desse processo, consultar Lui (2007). 
cente procuraria levar o aluno a reconhecer "também na dimensão religiosa, os modos pelos quais o homem procura dar respostas às suas interrogações existenciais". $\mathrm{Na} 7^{\mathrm{a}}$ ou na $8^{\mathrm{a}}$ série, o Ensino Religioso constituiria propriamente uma disciplina, que abrangeria a história das religiões, particularmente no Brasil; as relações entre religião e política; a questão antropológica da morte, assim como as relações entre a religião e os mitos.

No mesmo ano, o governador do Estado de São Paulo, Geraldo Alckmin, baixou o Decreto 46.802/02, reafirmando a orientação dada pelo Conselho Estadual de Educação, e destacou os princípios do Ensino Religioso, entendido como o ensino das "Ciências da Religião". Os pontos principais do decreto foram no sentido de assegurar o caráter supraconfessional do Ensino Religioso e o condicionamento de sua implementação à audiência do Conselho de Ensino Religioso do Estado de São Paulo, formado por instituições lideradas pela Igreja Católica, assim como por "outras entidades religiosas", não nomeadas. No que diz respeito ao conteúdo, o decreto diz que o Ensino Religioso deve "assegurar o respeito a Deus, à diversidade cultural e religiosa, e fundamentar-se em princípios de cidadania, ética, tolerância e em valores universais, presentes em todas as religiões". Ao mesmo tempo, o decreto afirma a proibição ao proselitismo nas escolas públicas, assim como qualquer manifestação em desacordo com o direito dos alunos e de suas famílias de professarem um credo religioso "ou mesmo de não professar nenhum". Permaneceu inalterada a obrigatoriedade implícita do Ensino Religioso nas séries iniciais, para os alunos e para os docentes.

Assim, a pretensão de Francisco Campos, de que a religião se estendesse para além de seu âmbito próprio, encontrou seguidores contemporâneos no Estado de São Paulo. O decreto do governador Alkmim, baixado sete décadas depois, contém o mesmo fundamento: há valores éticos universais, isto é, que estão presentes em todas as religiões.

Ora, se há valores universais, eles são valores políticos, não religiosos. Valores políticos podem até mesmo ter origem numa religião particular. Por exemplo, a dignidade da pessoa humana, pregada pelo Cristianismo, foi assumida como valor político pela sociedade. É justamente por ser um valor político que ele está proclamado no artigo $1^{\circ}$. da Constituição Federal. $\bigcirc$ resultado é que o Estado tem o dever de velar por esse valor, não por um imperativo religioso, mas por uma determinação política, que concerne a todos: aos cristãos, católicos e evangélicos; aos adeptos de outras religiões; aos agnósticos e 
também aos ateus. Por sua vez, o alegado universalismo dos valores religiosos não resiste à análise comparada, se ela for além do tronco judaico-cristão.

Não é descabido pensar que a imputação ao conteúdo do Ensino Religioso como sendo os "valores", possa ter dois propósitos: o reforço da hegemonia católica no campo religioso, cada vez mais diverso e conflitivo; e contornar a crítica laica, manifesta ou latente, diante do Ensino Religioso nas escolas públicas.

Nem mesmo tinha secado a tinta da assinatura do Presidente Fernando Henrique Cardoso no documento em que promulgou a segunda LDB, em dezembro de 1996, ele próprio manifestou a intenção de promover a mudança do artigo 33, que tratava do Ensino Religioso nas escolas públicas. O presidente se referiu, diretamente, ao fim da proibição de uso de recursos públicos para essa disciplina. $\bigcirc$ apelo foi eficaz, pois o projeto do MEC se somou a dois outros, de prestativos deputados interessados em oferecer serviço aos promotores da segunda visita do papa João Paulo II ao Brasil. Um projeto substitutivo foi elaborado pelo deputado Padre Roque, que, tramitando em regime de urgência, foi aprovado por voto de lideranças.

A nova redação do artigo 33 da LDB revela três aspectos importantes da luta nem sempre explícita no campo educacional. Em primeiro lugar, foi suprimida a proibição ao uso de recursos públicos para o Ensino Religioso?. Em segundo lugar, foi incluída no texto da LDB a determinação absurda de que o Ensino Religioso faria "parte integrante da formação básica do cidadão". Isso revela o sentimento de autorreferência (para dizer o mínimo) dos religiosos hegemônicos no país, a ponto de suporem que as crianças que não tiverem essa disciplina na escola pública, por impossibilidade de seu oferecimento ou por opção dos pais, ficariam com uma formação insuficiente ou defeituosa. Em terceiro lugar, aquela lei suprimiu do texto da LDB a possibilidade (pelo menos explícita) de oferecimento dessa disciplina na forma confessional. Provavelmente, os assessores jurídicos terão mostrado a dificuldade de se defender o confessionalismo diante da arguição da separação Estado-organizações religiosas, também chamada Estado-Igreja. Sendo criadas "entidades civis", constituídas por diferentes confissões (mesmo que sejam todas do tronco judaico-cristão

9. A primeira LDB também vedava o uso de recursos públicos para o Ensino Religioso, mas a proibição foi suprimida pela Lei n. 5.692/7I, promulgada em plena ditadura militar, no mesmo ano em que um cardeal, membro do Conselho Federal de Educação, deu seu parecer sobre a Educação Moral e Cívica, de conteúdo ostensivamente religioso. No próximo item focalizarei esse parecer. 
ou hegemonizadas por elas), o Estado poderia "ouvi-las" na definição do conteúdo do Ensino Religioso ${ }^{10}$. Estariam, assim, dribladas as acusações de favorecimento religioso.

Com o acirramento da crise econômica e dos conflitos sociais, desde os anos 1990, a religião virou uma panacéia, defendida, surpreendentemente, por religiosos e ateus. Um remédio para todos os males, que se pretende ministrar em doses amplas aos alunos das escolas públicas, como um mecanismo de controle individual e social supostamente capaz de acalmar os indisciplinados, de conter o uso de drogas, de evitar a gravidez precoce e as doenças sexualmente transmissíveis, apresentando-se, também, como a única base válida para a Ética e a cidadania, como se fosse uma espécie de educação moral e cívica do bem.

Postula-se a aplicação a todos os alunos de uma espécie de média ideológica, como se existisse um repertório de crenças comuns a todas as religiões, média essa que se pretende seja o conteúdo do ensino religioso inter ou supraconfessional, dotado, então, de legitimidade para integrar o currículo da escola pública, mesmo no Estado laico.

Ora, o campo religioso é necessariamente marcado por disputas pela hegemonia que assume ora a versão suave da missão, ora a aliança ocasional chamada ecumenismo, mas que pode chegar à competição ostensiva, em diversos graus e com diversas consequências. No passado como no presente, as disputas religiosas levam à guerra, ao terrorismo, à tortura e à censura. Nada disso diminui o entusiasmo para com as supostas virtualidades da panacéia religiosa na educação escolar.

\section{3․ MOVIMENTO: A EDUCAÇÃO MORAL E CÍVICA}

Como já foi dito, a disciplina Moral ou Educação Moral e Cívica foi implantada e suprimida dos currículos escolares em diferentes momentos do

10. Essa medida preventiva revelou-se desnecessária, pelo menos a julgar pelo sucesso do projeto que resultou na Lei n. 3.459/2000 (RJ), que instituiu o Ensino Religioso confessional na rede estadual fluminense e previu o concurso de professores dessa disciplina, por credo. Todas as ações que arguiram a inconstitucionalidade dessa lei, assim como das medidas nela baseadas, foram derrotadas na justiça, tanto na instância estadual quanto na federal. Uma ação direta de inconstitucionalidade, movida pela Confederação Nacional dos Trabalhadores na Educação, com o mesmo propósito, aguarda julgamento no Supremo Tribunal Federal. 
período republicano. No Estado Novo (1937/45), ela foi inserida nos currículos escolares, mas o crescente envolvimento do Brasil na luta contra o Eixo retirou seu suporte político-ideológico. Isso não impediu, contudo, que fossem produzidos livros didáticos para a Educação Moral e Cívica, alguns deles publicados pelo famigerado Departamento de Imprensa da Presidência.

Depois de cair na obscuridade, transformada em apenas algo a se "levar em conta" no currículo, durante a República Populista (1946/64), a Educação Moral e Cívica veio a ser retomada pelos militares que desfecharam o golpe de Estado de 1964. Mas o novo enxerto nos currículos escolares encontrou resistências no âmbito do Conselho Federal de Educação, que, por algum tempo, conseguiu escantear as propostas provenientes da Escola Superior de Guerra. Baixado o Ato Institucional n. 5, em dezembro de 1968, e deposto o vice-presidente Pedro Aleixo, em setembro do ano seguinte, a Junta Militar que ocupou a Presidência da República determinou a implantação daquela disciplina pelo Decreto-lei n. 869/69. A partir de então, a Educação Moral e Cívica passou a integrar, obrigatoriamente, os currículos escolares de todos os graus e modalidades de ensino do país. No ensino superior, ela assumiria a forma de Estudos de Problemas Brasileiros.

Apoiando-se nas tradições nacionais, essa disciplina teria por finalidade: a. a defesa do princípio democrático, através da preservação do espírito religioso, da dignidade da pessoa humana e do amor à liberdade com responsabilidade, sob a inspiração de Deus; b. a preservação, o fortalecimento e a projeção dos valores espirituais e éticos da nacionalidade; c. o fortalecimento da unidade nacional e do sentimento de solidariedade humana; d. o culto à Pátria, aos seus símbolos, tradições, instituições, e aos grandes vultos de sua história; e. o aprimoramento do caráter, com apoio na moral, na dedicação à família e à comunidade; f. a compreensão dos direitos e deveres dos brasileiros e o conhecimento da organização sociopolítico-econômica do País; g. o preparo do cidadão para o exercício das atividades cívicas, com fundamento na moral, no patriotismo e na ação construtiva visando ao bem comum; h. o culto da obediência à lei, da fidelidade ao trabalho e da integração na comunidade.

As finalidades da Educação Moral e Cívica representavam uma sólida fusão da doutrina de segurança nacional, conforme era concebida pela Escola Superior de Guerra com o catolicismo conservador. Não foi por acaso que o 
relator do Parecer n.94/7I, do Conselho Federal de Educação, que a normatizou, foi o arcebispo Luciano José Cabral Duarte.

Apesar do parecer do arcebispo-conselheiro proclamar que a Educação Moral e Cívica devesse ser aconfessional, isto é, não vinculada a religião específica alguma, a incorporação das doutrinas tradicionais do catolicismo e de seus quadros não era sequer disfarçada. Com efeito, o parecer proclamava que a religião é a base da moral a ser ensinada. Para escapar do paradoxo, o arcebispo lançou mão do conceito de "religião natural", isto é, aquela que levaria ao conhecimento de Deus pela luz da razão. Assim, ficavam afastadas várias religiões, inclusive as da matriz afro-brasileira, apesar de efetivamente praticadas por dezenas de milhões de pessoas, relegadas à condição de resíduos de ignorância ou de curiosidades folclóricas. $\bigcirc$ mesmo acontecia com as crenças indígenas, a despeito da celebração dos índios como os primeiros brasileiros.

A versão da Educação Moral e Cívica dos governos militares resistiu tempo demais, se comparada com sua aparição anterior no Estado Novo. Esta foi extinta imediatamente após a deposição de Vargas. Mas, o processo longo, tortuoso e contraditório da transição política da ditadura militar para a democracia, desde meados da década de 1970, permitiu uma surpreendente sobrevida a esse enxerto curricular. Foi só em 1993, que a lei n. 8.663 revogou o Decreto-lei n. 869/69, determinando que a carga horária dessa disciplina, "bem como seu objetivo formador de cidadania e de conhecimentos da realidade brasileira" fossem incorporados às disciplinas da área de Ciências Humanas e Sociais, a critério de cada instituição educacional'".

Mas, se a disciplina saiu do currículo, a ideologia subjacente persistiu como uma aspiração dos grupos situados à direita do espectro político-ideológico, que pretendem produzir a ordem social pela educação escolar. Nessa ideologia, a religião ocupa um lugar privilegiado.

Essa ideologia tem inspirado vários projetos de lei apresentados à Câmara dos Deputados e ao Senado, com o objetivo de inserir no currículo do ensino fundamental, do ensino médio e até do ensino superior disciplinas ou temas

1।. Na esteira da supressão da Educação Moral e Cívica, foi também retirada dos currículos escolares a disciplina Organização Social e Política do Brasil. Embora tratasse de temática distinta, ela havia sido demasiadamente contaminada por aquela para que sua importância fosse reconhecida. 
transversais (com e sem esse nome) sob diversos títulos, montados a partir dos termos Moral, Civismo, Cidadania, Ética, Direitos e Deveres.

Daniela Patti do Amaral (2007) ao examinar os projetos apresentados desde a promulgação da LDB, em dezembro de 1996, até o fim de janeiro de 2007, encontrou 13 projetos, apresentados por deputados de sete partidos ${ }^{12}$. Uns projetos tinham fundamentação religiosa mais explícita do que outros, mas o apelo aos valores religiosos era recorrente, assim como o resgate de valores que teriam sido perdidos.

Dentre os projetos examinados, escolhi como exemplo o que me pareceu mais conspícuo. Trata-se do Projeto de Lei n. 722, apresentado em 16/4/2003, pelo deputado Frankembergen Galvão da Costa, do Partido Trabalhista Brasileiro - PTB/RR ${ }^{13}$. Bacharel em contabilidade, delegado de polícia e pastor da Assembléia de Deus, o deputado apresentou projeto que previa a inclusão obrigatória, nas escolas oficiais de ensino fundamental e médio, da disciplina Estudo para a Moral e o Civismo. Ela teria, como finalidade,

.... difusão de valores fundamentais ao interesse social, aos direitos e deveres dos cidadãos, de respeito ao bem comum e à ordem democrática, através da preservação do espírito religioso, da dignidade da pessoa humana e do amor à liberdade com responsabilidade, sob a inspiração de Deus. (grifos meus)

Adiantando-se a possíveis críticas, o proponente esclareceu que não pretendia a interferência do Estado definindo a religião a ser objeto da nova disciplina. Apenas a "diretriz geral, o fundamento filosófico" seria estabelecido pela lei. Em seu projeto, Deus teria sido citado de "maneira ecumênica”, sem favorecer uma religião específica, como se houvesse consenso sobre a divindade.

É interessante notar que o pastor-deputado lamentou, na justificativa do projeto, a extinção da Educação Moral e Cívica, tal como definida pelo

12. O Partido Movimento Democrático Brasileiro - PMDB - contribuiu com três projetos; o Partido da Frente Liberal - PFL -, o Partido Democrático Trabalhista - PDT - e o PTB, com dois cada; e o Partido da Social Democracia Brasileira - PSDB -, o Partido Liberal - PL - e o Partido Progressista - PP - com um cada. Um projeto foi apresentado por deputado sem partido.

13. Com o nome político de Pastor Frakembergen, o então deputado do Partido Trabalhista Brasileiro passou pelo Partido Popular Brasileiro e, depois, tornou-se presidente nacional do Partido Social Cristão. 
Decreto-lei n. 869/69, que, segundo ele, teria sido "violentamente revogado em 1993, sem sequer observar seus detalhes de acolhimento aos deveres dos cidadãos, patriotismo e civismo".

O projeto foi rejeitado pela Comissão de Educação da Câmara dos Deputados e arquivado, mas, inconformado, o deputado o reapresentou em janeiro de 2006. Como o proponente não foi reeleito, o projeto revivido foi arquivado, como determina o regimento da Câmara.

Diante da profusão de projetos de enxerto curricular, Amaral (2007) pergunta-se, na conclusão de seu artigo: "Seria a inclusão da Ética e da Moral e Cívica na escola um movimento disfarçado para ocupar o lugar do Ensino Religioso de forma obrigatória e não facultativa?"

\section{CONSIDERAÇÕES FINAIS}

Vimos que os currículos escolares são objeto de vários tipos de enxertos, mas o foco do artigo recaiu sobre a inserção de elementos de caráter políticoideológico. A Ética não foi enxertada pelos Parâmetros Curriculares Nacionais para o Ensino Fundamental. Ela foi corretamente definida como tema transversal pelos PCN, a partir de dentro do campo educacional. Mas, de fora do campo, dois tipos de disciplinas foram enxertadas - o Ensino Religioso nas escolas públicas e a Educação Moral e Cívica, esta sob diversas denominações. A "sintonia oscilante" entre o Ensino Religioso e a Educação Moral e Cívica, assinalada em artigo anterior (Cunha, 2007), tende a dar lugar à reciprocidade pedagógica, uma disciplina incluindo conteúdos da outra. A sintonia entre elas consiste, hoje, tendencialmente, nos "valores" (éticos e/ou cívicos) como conteúdo do Ensino Religioso, ao que corresponde a religião como pauta da Educação Moral e Cívica.

Embora seja legítima a ação do Congresso Nacional sobre os sistemas educacionais, inclusive sobre o que neles se ensina, a enxertia aqui focalizada expressa a ação de grupos religiosos que pretendem utilizar o Estado, especialmente as redes públicas de ensino, para a difusão de crenças e para a competição interna ao campo religioso. Em consequência, um tipo de ação política, em princípio legítima, resulta em prejuízo para a educação pública. E isso por três razões: I. A enxertia curricular retarda o processo de autonomização do campo educacional, processo esse que tem sofrido recuos nos períodos ditatoriais. Não pretendo sugerir que o campo educacional baste a si 
mesmo, que se isole das decisões políticas, como se isso fosse possível, mas, sim, defender o avanço de sua autonomização, ainda débil. Tampouco pretendo sugerir que o campo educacional seja homogêneo. Com efeito, as pressões antiautonomização são geradas, também, de dentro das escolas, pelos próprio professores, especialmente pelos militantes religiosos. 2. A enxertia provoca o congestionamento curricular. Parece que foram esquecidas as críticas, há tanto tempo dirigidas à escola brasileira, como tendo um currículo enciclopédico. Essa tendência pode aumentar por causa de uma pretensa valorização da escola, que a presume instrumento da solução dos mais diversos problemas sociais. 3. A enxertia aqui focalizada gera uma contradição insolúvel entre os valores da Ética laica, isto é, que concerne a todos, crentes e não crentes; e uma Ética de natureza religiosa, que concerne a cada grupo de crentes. $\bigcirc$ efeito mais dramático dessa contradição é a disciplinarização da Ética, que, de tema transversal previsto nos PCN, tem-se convertido em conteúdo particularizado, até mesmo do Ensino Religioso.

Sobre esse último ponto, cumpre explicitar que o conflito resultante dessa contradição não deve ser ignorado nem dissimulado. Acerca disso, manifestei-me anteriormente, no sentido que agora reitero. A tentativa de inserir a Ética laica no ensino público merece o apoio de todos os que rejeitam a pretensão de certos grupos de monopolizarem o controle da moral coletiva, seja o clero de alguma sociedade religiosa, o comissariado de algum partido político, a censura de algum governo ou de grupo de interesse. A explicitação dessa disputa não desqualifica a Ética laica nem a expõe a ataques novos. Os grupos empenhados em utilizar a escola pública para controlar a moral coletiva ou para resolver disputas próprias do campo religioso estão na ofensiva, de modo que não cabe adiar essa explicitação. No momento em que vivemos, quando as tenebrosas consequências dos fundamentalismos, especialmente do ramo judaico-cristão-muçulmano, são visíveis em todo o mundo, a defesa do ensino público laico - e de um Estado laico, antes de tudo - impõe-se como um item prioritário no ideal democrático (Cunha, 1996, p.71).

Voltemos, então, às perguntas feitas no início do artigo: Ética se aprende na escola? Como se dá esse aprendizado e como ele deve ser desenvolvido? Minha resposta é afirmativa. Ética se aprende na escola, como na família, nos filmes, noticiários e anúncios dos meios de comunicação de massa, nas competições esportivas, nas campanhas políticas e em outras situações significativas. 
Todavia, nem a família nem a escola são os lugares mais importantes para a formação ética. A família tem sido a idealização maior dos grupos conservadores, que supõem em geral uma forma familiar específica (pai, mãe e filhos em convivência duradoura). A família nuclear pequeno-burguesa estaria supostamente dotada de valores positivos, crença que não resiste à mais elementar análise objetiva. A escola, por sua vez, tem sido projetada por uma ideologia que idealiza a instituição e os próprios professores.

Reconhecer no entanto, a "isonomia" de todas essas instituições na formação ética não implica desconsiderar o papel da escola. Significa, isto sim, reivindicar para ela uma pedagogia apropriada, que não é a do programa de ensino, mas a do exemplo. Convenhamos: não há nada mais educativo do que o exemplo dos professores e demais profissionais da educação nas relações entre si e com os alunos, no âmbito das práticas administrativas e pedagógicas do dia a dia. Como, aliás, diz o ditado: uma ação vale mais do que qualquer preleção.

\section{REFERÊNCIAS BIBLIOGRÁFICAS}

AMARAL, D. P. Ética, moral e civismo: difícil consenso. Cadernos de Pesquisa, São Paulo, v.37, n. I3I, p.35I-369, maio/ago. 2007.

BRASIL. Ministério da Educação. Secretaria de Educação Fundamental. Parâmetros curriculares nacionais: apresentação dos temas transversais: ética. Rio de Janeiro: DP\&A, 2000.

Parâmetros curriculares nacionais: introdução aos parâmetros curriculares nacionais. Rio de Janeiro: DP\&A, 2000a.

CAMPOS, F. Educação e cultura. Rio de Janeiro: José Olympio, 1940.

CUNHA, L. A. Os Parâmetros curriculares para o ensino fundamental: convívio social e ética. Cadernos de Pesquisa, São Paulo, n.99, p.60-72, nov. 1996.

Sintonia oscilante: religião, moral e civismo no Brasil, 1931/97. Cadernos de Pesquisa, São Paulo, v.37, n. 13 I, p.285-302, maio/ago. 2007.

LUI, J. de A. Entre crentes e pagãos: ensino religioso em São Paulo. Cadernos de Pesquisa, São Paulo, v.37, n. I31, p.333-349, maio/ago. 2007.

MOREIRA, A. F. B. A Psicologia... e o resto: o currículo segundo César Coll. Cadernos de Pesquisa, São Paulo, n. 100, p. 109-123, mar. 1997.

OLIVEIRA, R. J. A Ética na educação escolar: um olhar laico. (texto captado do Observatório 
A luta pela ética...

da Laicidade do Estado). Disponível em: http://www.nepp-dh.ufrj.br/ole/textos_equipel. html. Acesso em: 6 out. 2008.

TAILLE, Y.; SOUZA, L. S.; VIZIOLI, L. Ética e educação: uma revisão da literatura educacional de 1990 a 2003. Educação e Pesquisa, São Paulo, v. 30, n. I , p.9l - I08, jan./abr. 2004.

Recebido em: janeiro 2009

Aprovado para publicação em: janeiro 2009 